\title{
Comprehensive Reform of Education through Collaboration between Industry and University in Visual Communication Art under the Background of Large-scale IT Industry
}

\author{
Hui Xie \\ Heihe University \\ Heihe, China
}

\author{
Xiaoli Zhang \\ Heihe University \\ Heihe, China
}

\begin{abstract}
Current situation of specialty of visual communication art under the background of large-scale IT industry is analyzed. Problems in comprehensive reform of education through collaboration between industry and university and corresponding measures are proposed. This paper elaborates the necessity of promoting the comprehensive reform in education through collaboration between industry and university in the specialty of visual communication art.
\end{abstract}

Keywords-large-scale IT industry; specialty of visual communication art; cooperation between industry and university; collaborative education

\section{INTRODUCTION}

Professor He Jie in Academy of Arts and Deign in Tsinghua University addresses the appearance of digital media makes social environment have qualitative changes since the 20th century. Static media fails to meet demands in new century. Digital media also changes connotation of original visual communication art and produces UI interface design in new visual communication design which are extensively applied in smart phone, tablet PC and other touch screen mobile devices. The large-scale IT industry requires an increasing number of students in specialty of visual communication design and has higher requirements for students' professional level. Comprehensive reform of education through collaboration between industry and university will train skilled talents who meet requirements of economic and enterprise development. It is a major transformation of education model in higher vocational education.

\section{CURRENT Situation OF SPECIALTy OF VisuaL COMMUNICATION ART UNDER THE BACKGROUND OF LARGE- SCALE IT INDUSTRY}

\section{A. Fail to Meet Social Demands}

IT industry of our country develops rapidly and forms large scale in recent years. According to the statistics, the number of mobile internet users in our country has reached 800 million. 4G smart phones and tablet PC are widely used around the world. The soaring development of internet industry derives new field of visual communication design namely UI interface design. Enterprises are in urgent need of UI design talents and compete for compound talents who grasp UI design and apply it to client side. However, higher vocational colleges neither see the huge demand nor timely establish training objectives and provide courses of UI interface design for students, so they cannot meet market demands through talent supply. At present, only several schools like Guangzhou Academy of Fine Arts, Beijing Film Academy, Jilin Animation Institute and Sichuan Fine Arts Institute provide course of UI interface design.

\section{B. Course System in Specialty of Visual Communication Art Is Unsound.}

Three modules of "foundation course", "specialized course" and "design practice" form the course system of visual communication art in most universities. Course contents focus on traditional logo design, book design, graphic creativity design and VI design instead of UI interface design. The design of specialized course is rigid and neither combines with the reality nor caters to the trend of social development, so it is difficult to train UI design talents that meet the requirements of social development.

\section{PROBLEMS IN COMPREHENSIVE REFORM OF EDUCATION THROUGH COLLABORATION BETWEEN INDUSTRY AND UNIVERSITY IN SPECIALTY OF VISUAL COMMUNICATION ART UNDER THE BACKGROUND OF LARGE SCALE IT INDUSTRY}

At present, the most prominent problem in specialty of visual communication art is that talent training fails to meet the demands of social development. In collaborative education, schools and enterprises cannot find a proper opportunity. Enterprises are negative in this process.

\section{A. Educational Concepts Are Outdated and the System of Cooperation between Industry and University Is Unsound}

In education in specialty of visual communication design through cooperation with enterprises, universities neither set training objectives of talents related to requirements of enterprises nor make contents of visual design meet actual 
demands of enterprises. Cooperation between school and enterprise are theoretical, or cooperative practice bases are established but innovation training is not provided according to physical truth. They follow traditional teaching methods and make the cooperation between industry and university meaningless. Students' substituted post exercitation and employment after graduation has little relationship with enterprises, so that many students lack sustainable development. The cooperation between school and enterprise neither improve the innovation level of schools nor meet demands of enterprises.

\section{B. Policies and Regulations Are Incomplete}

Education through collaboration between industry and university is an innovative model to improve the collaborative innovation capacity of university and meet the requirements of society for high skilled talents. But relevant policies and regulations related to it are incomplete. Most are guiding proposals that neither strictly normalize the procedures nor specifically state the evaluation criterion. Preferential measures for enterprises are not implemented, and employment security system for students after graduation. Because this pattern just starts in our country and there are no successful cases to refer, universities can only cross the river by feeling the stones and have difficulty in implementation.

\section{University and Enterprise Have Conflict of Interest}

Enterprises are organizations aiming at making profits, but schools are public beneficial. Students in specialty of visual communication art will have difficulty in carrying out substituted post exercitation in enterprise. The primary cause is that they have conflict of interest. Enterprises hope to treat students as free labor forces. Under this circumstance, students cannot learn real skills and are unsatisfied about the effects of training skills.

IV. MEASURES TO PROMOTE COMPREHENSIVE REFORM IN EDUCATION THROUGH COLLABORATION BETWEEN INDUSTRY AND UNIVERSITY IN SPECIALTY OF VISUAL COMMUNICATION ART UNDER THE BACKGROUND OF LARGE-SCALE IT INDUSTRY

"2011" Plan was launched in May 2012, namely the ability improvement plan of university, referring to a significant innovation related to talent training in university field after Project 211 and Project 985. It proposes in "2011 Plan" that uses reform of institution and mechanism to lead the collaborative innovation and uses collaborative innovation to lead the comprehensive improvement of innovation capacity of university. The core mission of "2011 Plan" is to improve the innovation capacity of talents, disciplines and scientific research.

Zhang Li in National Education Center observes the 2011 Plan is designed through aiming at deep collaboration between industry and university, involves enterprises, universities and scientific research institutions and finds coherence point through the platform to transform it into productivity. According to the demands of "2011 Plan", universities must cooperate with enterprises, absorb innovative force in enterprises and exploit the advantages to the full like comprehensive disciplines and extensive functions, in order to build an innovative platform and improve innovation capacity.

\section{A. Set up Specialties According to Market Demands}

Universities should meet demands of social development and follow the development of times to improve quality of talent training. Under the background of large-scale IT industry, universities must timely adjust specialty of visual communication art and bring in post capacity model of benchmarking enterprises in internet industry and cooperate with enterprises to formulate standard and certification system of this post, in order to train knowledge, skills and comprehensive quality of students and make them meet social demands. In this process, universities can make investigation and survey on development situation of this industry and market demands, seriously analyze the current situation of internet industry and the development tendency of UI design post, in order to let students have sustainable development. Moreover, they should discuss with enterprises and relevant departments of enterprises to ensure students trained in this specialty can meet demands of social development. The construction of specialty is uneasy and needs continuous adjustment according to physical truth, requiring universities to keep in close contact with enterprises and constantly pay attention to the development and change of IT industry.

\section{B. Formulate Training Program That Meets Job Requirements}

University should formulate training program of talents in visual communication art according to the talent standard of post capacity model and talent posts co-constructed by school and enterprise, in order to train UI design talents urgently required by society. Educational objectives of universities are to let students obtain the education background of regular higher education. Besides, it makes students competent in the occupation and post to play a constructive role.

\section{Construct Reasonable and Dynamic Course System Related to UI Design}

"When training talents according to actual demands of posts in higher vocational education, universities should base on needs of enterprises and society as well as actual demands of posts in major setup, curriculum provision and training measures." The setup of course system in university should train students' level in visual communication art and improve students' integrated quality to make UI designers meet demands of society and enterprises. University arranges course contents of specialty according to the needs of posts for students' knowledge and skills. According to [2006] No. 16 document issued by the Ministry of Education, higher vocational colleges shall cooperate with enterprises to develop courses and reform course system and teaching contents in accordance with job requirements of technical field and professional post and relevant standards of vocational qualification. Colleges and enterprises jointly formulate curriculum standards related to UI design and develop courses according to actual needs of posts, in order to realize win-win. They should deeply analyze capacity and knowledge structure required by the post of UI design, bringing standards and 
requirements of this post into courses. Colleges invite enterprises to evaluate students' school work and ensure it can conform to the reality of posts from course development to the completion of teaching objectives.

\section{Strengthen the Construction of Teaching Staff of UI Design}

Colleges must have higher requirements for efficient teachers. Teachers must grasp theoretical knowledge in UI design and have operation level on UI design practice. In collaborative education, schools and enterprises should encourage teachers to enter enterprise and learn on a certain post, in order to feel the requirements for talents in UI design. It has requirements on technology of UI design and comprehensive quality. Meanwhile, colleges understand recent news of enterprises and IT industry and the latest changes of this post and cooperate with staff of enterprises to solve problems and improve teachers' practice ability. On the other hand, schools can employ professionals of UI design or employ professional UI designers of enterprises to do part-time job, in order to make teaching staff with high professional level.

\section{E. Improve Matched Policies and Regulations}

In collaborative education, enterprises only participate formally instead of playing a dominant role. It is because policies and regulations matched with education through collaboration between industry and university are unsound and there are no corresponding compensating measures for enterprises. The primary purpose of enterprises is to make profit. The cooperation between industry and university will diffuse the energy of enterprises and undoubtedly make UI designers in shortage busier. It may lower efficiency and earnings of enterprises. Students will not bring benefits for enterprises when practicing on UI post but enterprises have to pay them. It increases the cost of enterprises. Therefore, corresponding compensations should be given to enterprises and staff in enterprises responsible for cooperation between industry and university. Furthermore, the cycle of training UI design talents is long. Enterprises in urgent need of these talents cannot wait so long. Students not always work in the company after graduation. Large enterprises with enormous potentiality are not inclined to cooperation between industry and university. Instead, they attract excellent talents who can create benefits immediately from abroad to solve the matter of extreme urgency. These large companies have internal quick, convenient and efficient post training system to train employees systematically. Small enterprises short of UI design talents have no strength to introduce talents or cooperate with schools. In the cooperation between industry and school, many colleges only become formalistic and fail to participate in course design and arrangement. The improvement of policies and regulations can normalize the phenomenon and intensify the compensation for enterprises to participate in education through cooperation between industry and university, in order to promote the comprehensive reform in education through cooperation between industry and university in the specialty of visual communication art.

\section{NECESSITY OF COMPREHENSIVE REFORM IN EDUCATION THROUGH COOPERATION BETWEEN INDUSTRY AND UNIVERSITY IN SPECIALTY OF VISUAL COMMUNICATION ART UNDER THE BACKGROUND OF LARGE-SCALE IT INDUSTRY}

Cooperation between industry and teaching is integration between industry and teaching, which is first proposed by technician training school in Wuxi city of Jiangsu, in order to improve students' learning quality. It means making every endeavor to seek products closely combined with production and practice so as to improve students' quality consciousness, product consciousness, sense of time and operational ability. Integration between industry and teaching was proposed on journals like Chinese Vocational and Technical Education, China Labor and Social Security News in 2007. The Ministry of Education proposed the requirements of "promoting deep cooperation between industry and teaching" in Opinions on Acceleration the development of Vocational Education in Rural Areas in 2011. What are the necessities to attach importance to the cooperation between industry and university? They are concluded as follows.

\section{A. Train skilled talents}

Colleges should value the actual needs of social development to train high quality talents urgently needed by the society. Students can acquire and grasp knowledge in shortterm training but acquire skills through long-term practice. It is a progressive process without shortcuts. Occupational qualities are developed in work and the result formed through influence of occupational environment. The traditional educational patterns neither keep up with the trend of the times to train talents required by the society nor help the cultivation of students' occupational qualities. The promotion of comprehensive reform in education through cooperation between industry and university in specialty of visual communication art enables students to improve UI design skills, let them integrate in occupational environment and develop good occupational qualities, in order to work better in the future.

\section{B. Improve Quality of Talent Training}

Colleges shoulder the important mission of training high skilled talents and their comprehensive quality to make them meet the needs of social development. In order to accomplish the mission, colleges must reform under new situation, promote the comprehensive reform of collaborative education and train UI design talents with higher quality.

\section{Enterprises to Improve Production Efficiency}

The primary purpose of enterprises is to make profits. If enterprises can make profits in this process or at last, they will be willing to carry out education through cooperation with schools. Otherwise, they have no enthusiasm to cooperate with schools. The cooperation between industry and university will become formalistic. Students will learn nothing in UI design class. 


\section{Requirements of Concrete Contents in Cooperation between Industry and University}

Most importantly, colleges must connect specialty with industry, school with enterprises, course contents with occupational standard, teaching process with production process, academic certificate with job qualification certificate, so that they can complete cooperation between industry and schools and improve students' quality and skills. At the meantime, the five connections also promote the deep integration of cooperation between industry and university.

\section{CONCLUSION}

Education through collaboration between industry and university must respect development law of market economy. Government must guarantee from policy and economy. Schools should train qualified UI design talents according to actual demands of enterprises. Enterprises should participate in course arrangement in the cooperation to promote the comprehensive reform in specialty of visual communication art.

\section{REFERENCES}

[1] Wang Xiaodan. New Pattern of Integration Training of Compound Talents with "Talent, Virtue and Ability"-Education through Collaboration between "Universities" and "University and Enterprise" in "3 Plus 4" Computer Graphic Design and Visual Communication Design [J], Journal of Changzhou Institute of Technology (Social Science Edition), 2016, 34(3): 108-110

[2] Shang Ming. Research on Building Development Pattern of Collaboration between Industry and University in Specialty of Visual Communication Design [J], Appreciation, 2016(6)

[3] Xu Dongdong. Thinking on Promoting Higher Vocational Education through Collaboration between Industry and University [J], Continue Education Research, 2014(4): 43-44

[4] Xu Mingcheng, An Jing. Construction of Collaborative Education Mechanism Based on Collaboration between Industry and UniversityTake Training of Network Marketing Talents as Example [J], Journal of Chifeng College: Natural Science Edition, 2015, 31(4): 215-217

[5] Wang Chunmei. Analysis on Talent Training Program of Art and Design in Higher Vocational Education through Taking Employment as the Orientation-Take the Specialty of Visual Communication Art in Department of Humanities and Arts of Nanjing Vocational Institute of Transport Technology as an Example [J], Journal of Hunan Industry Polytechnic, 2012(4): 154-155 